\title{
Water Scarcity And The Impending Water-Related Conflicts In Nigeria: A Reappraisal
}

\author{
Gusikit, R.B., and Lar, U.A., \\ Department of Geology and Mining, University of Jos, Jos-Nigeria
}

\begin{abstract}
Until fairly recently, water has been seen as an infinitely available resource to be diverted, drained or polluted in generating wealth. Scarcity is a policy-induced outcome flowing from this deeply flawed approach, the predictable consequences of inexhaustible demand chasing an under priced resources.

This study seeks to look at water resources in Nigeria and to assess water availability and its attendant consequences on the Nigeria population at present and in the near future. Images of shrinking lakes, and disappearing of rivers, population growth, pollution and climate change reinforce the perception that Nigeria is drifting into water crises. With competition for an increasing scarce resource conflicts within the country and water wars between countries are likely inevitable. This study seeks for ways of providing solutions to water crises that may arise between Nigeria and other countries sharing rivers together.
\end{abstract}

Keywords: Water, Scarcity, Conflict, Crises, Nigeria.

\section{Introduction}

Water is unknowingly the second most precious natural resources on earth after air. Oil has always been thought of as the traditional cause of conflict in Nigeria in the past and in the present. The importance of water to man cannot be over emphasized. He can survive longer without food than without water. Man requires water for cooking, washing, sanitation, drinking, transportation, agriculture and running of industries. Therefore, modern man like his primitive ancestors is heavily dependent on water for his sustenance. Water is taking over from oil as the likeliest cause of conflict in Nigeria in time to come.

A shortage of water resources could spell increased conflicts in the future. The conflict can be caused by competition for increasingly scarce resource. Conflicts associated with water scarcity are food scarcity and regional instability. Population growth will make the problem worse, so will climate change. As the global economy grows, so will the competition for the available water supplies continue to increase until some radical measures are taken. Many more conflicts lie just over the horizon.

The amount of water in the world is finite. The number of people is growing fast and our water use is growing even faster. A third of the world is facing water - stressed situation now. By 2025, this is expected to rise to two-third.

\section{Water Resources in Nigeria}

Water resources are sources of water that are potentially useful to humans. Water resources can be classified into surface water resources (rivers, lakes, streams, oceans, dams) andgroundwater resources (boreholes, wells, and springs).

Like in most African countries, surface water is the most widely use water resources in Nigeria because of its availability. In the early nineteen seventies, drought swept much of the Sahel regions of Africa, including Nigeria. People traveled long distance, rather aimlessly, with their livestock and water containers in search of water that was nowhere to be found. Infact, the re-emergence of another drought, after 10 years, that is in the nineteen eighties, confirms some kind of a cyclic pattern in the rainfall distribution

Sokoto region (Nigeria) experiences a short rainy period and a long dry season. The rainy season starts about mid-May in the southern fringes of the study area and about mid-June in the northern districts. The season ends about middle to late September in the northern districts, and early October in the southern districts. The dry season, on average, lasts between seven and eight months, usually from October to May. During the dry season the climate is dominated by the dry-dusty wind (harmattan), which blows Sahara dust over the land. When the dust hangs in the air, it causes serious air pollution which results in dirt virtually everywhere, and also reduces visibility. With an annual average temperature of $38.3{ }^{\circ} \mathrm{C}$, Sokoto is one of the hottest cities in Nigeria, with maximum daytime temperatures hovering between 35 and $40^{\circ} \mathrm{C}$ which makes this dry environment quite unbearable. The warmest months are February, March and April when daytime temperatures can exceed $45^{\circ} \mathrm{C}$ (Imo and Ekpenyong, 2011).

With this development in mind, it is clear that relying on surface water resources in the face of the prevailing adverse and unpredictable climatic condition is risky. 
Groundwater is very important resource. It is known to occur more widely than surface water (Offodile, 2002). Although Nigeria as a whole is rich in surface water resources, it is deficient in groundwater resources. This is because of the extensive area of the country covered by crystalline rocks of the Basement Complex which are poor aquifers. These rocks covered about $50 \%$ of the country but present or contribute little to the groundwater supply.

The Basement Complex rocks consist mainly of igneous and metamorphic rocks which are neither porous nor permeable except in areas where the rocks are weathered or fractured (Offodile, 2002). Although fold, fault, joints and shear zones are common, they are too localized to be of significant importance as reservoirs of water. Groundwater is exploitable naturally through springs, artificially through wells and boreholes.

In the areas underlain by sedimentary rocks, the success ratio of borehole digging is very high. Areas of sedimentary rocks include the coastal areas, southeast, the basins of the River Niger and River Benue, the Sokoto-Rima basin in the northwest and Chad basin in the northeast. Wells give reasonably good yields in all areas especially the riverine areas of Midwestern and River states. Artesian water occurs in the Chad basin and part of the Sokoto-Rima basin as well as in few locations in the Paleocene-Eocene sedimentary rocks of the western States.

\section{Water scarcity in Nigeria}

"Water scarcity" is a situation where the fresh water availability is below 1000 cubic meters per capital annually (Human Development Report, 2006). When the availability is below 500 cubic meters per capital annually, the situation is known as "absolute scarcity". The convention is to treat 1,700 cubic meters per person as the national threshold for meeting water requirements for agriculture, industry, energy and the environment. In general, a country with less than 1,700 cubic meters per capital annually is regarded as experiencing water stress ((Human Development Report, 2006).

The lists of water-scarce countries in 1955 were seven including three Middle Eastern countries: Bahrain, Jordan and Kuwait. By 1990, thirteen (13) were added among them, eight from the Middle East; Algeria, Tunisia, Israel, Palestine, Qatar, Saudi Arabia, Somalia, United Arab Emirates and Yemen.

United Nations studies anticipated an addition of another 10 countries by the year 2025. "Water scarcity" writes a commentator "will be the defining condition of life many in this new century" (United Nations, 1991). Images of shrinking lakes and disappearing rivers reinforce the perception that the world is drifting into crises, with competition for increasingly scarce resources driving conflicts within countries and causing water wars among countries (Gusikit, 2008).

\section{Evidences of water scarcity in Nigeria}

Water scarcity in Nigeria is evidenced by increased in population growth, pollution, climatic change and depletion of aquifers

\section{IV.1 Population growth}

Water scarcity is determined based on water availability and demand for it. The demand is based on the population of the nation. In Nigeria, the population is on the increase and increase in population leads to increase of water for food production and household use, which in turn, may exacerbate water shortage, food scarcity, and ultimately lead to economic and so social crises (Falkenmark, 1989a, and 1989b). From Table 1, water demand exceeds its availability. Demand is in trillion, while availability is in billion. This is an indication of water scarcity in Nigeria. Also, Table 2 shows the annual average yield of the major rivers supplying water for Nigeria. Without Rivers Niger and Benue that supply the highest amount of water into the country, there will be "absolute water scarcity" in Nigeria.

Table 1: Total volume of water available and utilization in Nigeria, 1991-2001

\begin{tabular}{|l|l|l|l|l|}
\hline Year & $\begin{array}{l}\text { Total Volume of Water } \\
\text { Available (billion } \mathrm{m}^{3} \text { ) }\end{array}$ & Population (million) & $\begin{array}{l}\text { Water per capital } \\
\text { annually (million ) }\end{array}$ & $\begin{array}{l}\text { Water } \\
\text { (trillion) }\end{array}$ \\
\hline 1991 & $4,223.8$ & 88.5 & 1,815 & 160627 \\
\hline 2000 & $5,675.8$ & 113.5 & 1,982 & 224957 \\
\hline 2001 & $6,546.6$ & 116.7 & 1,841 & 214844.7 \\
\hline
\end{tabular}

Source: (Christopher, 2006) 
Table 2: Distribution of annual average yield of surface and groundwater in Nigeria

\begin{tabular}{|l|l|l|}
\hline Hydrological area & $\begin{array}{l}\text { Average surface water annual yield 109 } \\
\left(\mathbf{m}^{\mathbf{3}}\right)\end{array}$ & $\begin{array}{l}\text { Average groundwater annual yield 109 } \\
\left(\mathbf{m}^{\mathbf{3}}\right)\end{array}$ \\
\hline Chad Basin & 8.2 & 5.6 \\
\hline North West & 22.4 & 4.3 \\
\hline Upper/ Lower Benue & 83.0 & 11.4 \\
\hline West Littoral & 35.4 & 9.0 \\
\hline Niger & 85.9 & 13.4 \\
\hline North Central & 32.4 & 8.2 \\
\hline Total & $\mathbf{2 6 7 . 3}$ & $\mathbf{5 1 . 9}$ \\
\hline
\end{tabular}

Source: (Christopher, 2006)

\section{IV.2 Pollution}

Pollution is exacerbated by the fast increasing Nigeria population. Sewages are dump into rivers, streams, and seas thereby polluting them with its attendant effects on human health. In Nigeria, another source of pollution is oil spillage into water systems especially in the oil rich Niger Delta. An excellent example is Akassa where the River Niger flows into the Atlantic, thereby destroying living organisms found in the ocean (Christopher, 2006).

\section{V.3 Shrinking of lakes, rivers, and disappearing of certain living organisms}

Lake Chad situated at the edge of the Sahara desert provides a vital source of water to human, livestock and wildlife communities (World Bank, 2002). Over the past decades, the region has experienced a series of devastating droughts (Eric et al, 2006). The lake is one of Africa's largest freshwater lakes, but has shrunk dramatically over 40 years; however, the shrinkage can only be regarded as a temporary, rather than permanent change. In the past, the lake has been as large as $25,000 \mathrm{~km}^{2}$ and in recent time as small as one-twentieth of its initial size. It is an extremely shallow lake, rarely more than $7 \mathrm{~m}$ deep.

Back-to-back droughts in the 1970's and 1980's have left the lake basin as well as the approaches of its management completely, if not permanently changed. The negative changes include the shrinkage of Chad and decrease flow pins, its specific plant species and reduction of canopy cover; loss of wildlife population; increase soil erosion and/or loss of fertility; reduction in rain-fed irrigated drops.

Water experts warn that the River Niger is threatened by drought, silting up, industrial waste and population. A Nigeria fisherman said that the River Niger had become shallower, making it harder to catch fish. Now, most of the place is covered by sand band. If there is no concerted action, there is the risk of River Niger drying up (Gusikit, 2008).

Habitat alterations are also threatening the rich tapestry of Niger River ecosystem. These include dams, which drastically alter the flow and sediment regimes of the river in the basin in addition to direct fragmenting and destroying aquatic habitats, irrigated floodplain agriculture, which displaces productive habitat for fish, livestock, and wild life and increasing discharge of sewage and other anthropogenic pollutants into rivers.

\section{VI.4 Climatic change}

Climatic events based on long term metrological data shows discernable evidence of climate change in the country (Imo and Ekpenyong, 2011). During the middle of the $20^{\text {th }}$ century (1941-1970), most parts of Nigeria had normal or onset of dates of rainy season except at Sokoto, Maiduguri, Calabar and environment where the rains come late (Imo and Ekpenyong, 2011). As the century progressed (1971-2000), the late onset had spread to more areas living only a narrow band in the middle belt and south west regions where normal conditions now prevail. In the middle of the century, the whole country had normal cessation of rainy season except some parts of south west which had early cessation (Imo and Ekpenyong, 2011). However, by the last part of the century, most part of the country had early cessation. The effect of this late unset and early cessation and cessation had manifested in the contradiction of the length of raining season.

Annual rainfall amount showed a decrease $2-8 \mathrm{~mm}$ per year across many parts of the country while few places like Lokoja, Kano, Ibadan and Ondo had increase in 2-4 mm per year across 1941-2000. The rainfall decrease is more significant at Port-Harcourt and Katsina (World Bank, 2002).

Generally, most parts of the country showed evidence of long term temperature increase except Jos area that is slightly cool. The extreme northeast, southwest and northwest, the temperature increases from $1.4^{0} \mathrm{C}-1.9^{0} \mathrm{C}$ (World Bank, 2002).

\section{Water-related conflicts in Nigeria}

Water conflicts are inevitable in Nigeria if we continue to do nothing to prevent them from occurring. The country's finite fresh water resources cannot continue indefinitely to support the escalating demands if drastic measures are not put in place to properly manage it. Competition for the available water supplies will continue to increase to the point where radical interventions are required. In addition, water conflicts that are 
linked to the position of international borders will still occur in those places where the countries concerned have not yet reached a joint agreement. Water - related conflicts in Nigeria will give rise to food scarcity and regional instability

\section{V.1 Food scarcity}

Food can be said to be the most important necessity for any life, both animal and human, to survive. It is disheartening that a country like Nigeria has been listed as one of the nations that are going to face food scarcity, despite all the human and natural resources that we have in the country large enough to feed the world (Oluwayinka, 2013).

The Federal Government has asked Nigerians to brace up for some hunger as the nation may be plagued by food scarcity owning to the effects of flooding that washed away farmlands and ravage residential quarters across the country. It is believed that if relevant stakeholders had prepared well and did not divert all their attention to the oil sector, may be the country would not have found itself in this mess (Oluwayinka, 2013).

There has been a dramatic increase in food prices around the globe for stable foods such as maize, lentils, flour, etc. These basic foods are the substance that many families around the world live on from day to day. When the costs of these essential foods rise, it dramatically affects those relying on them. For example, what used to take a day's wage to buy may now take three weeks wages (Oluwayinka, 2013).

Nigeria is particularly prone to food shortages due to the constant flooding and droughts the country is experiences. Natural disasters like flooding wipe out crops and diminish the food supply.Food shortages which can also be attributed to the lack of water, reduced rainfall, along with no good methods of capturing rainfall in basins or containers, both eventually lead to a lack of food in some form or another. People don't have the means to water their crops or irrigate their fields. There is also no water for livestock or even their own personal uses. (Oluwayinka, 2013).

\section{V.2 Regional Instability}

The River Niger is of great significance in the management of water resource, not only in Nigeria, but in other countries in West Africa sub-region. It is one of Africa's 55 international rivers, traversing in such countries as the Republic of Benin, Burkina Faso, Chad, Cote d'Ivoire, Guinea, Mali, Niger, Nigeria and Sierra Leone (World Bank, 1995). The River Niger is therefore a potential water-conflict zone (Figure 1). Other possible flashpoints in Nigeria are River Benue and Chad basins Figures 2 and 3. As shown on Table 2 above, River Benue (the Upper and Lower) and Lower Niger Rivers constitute a larger source of annual renewal water in Nigeria.

It has been estimated that in the next 25years, water will be the main source of conflict in Nigeria as other countries sharing rivers with Nigeria will fight for access to the scarce resources. If the population of Nigeria rises as predicted from 140 million in 2006 to 254.7 million in 2025 (Federal Republic of Nigeria , 2007), then there could be intense competition for the increasingly limited resource.

Since, water is already a catalyst for regional conflicts, the countries concerned should come together and agree on common criteria for the control and management of the scare commodity.

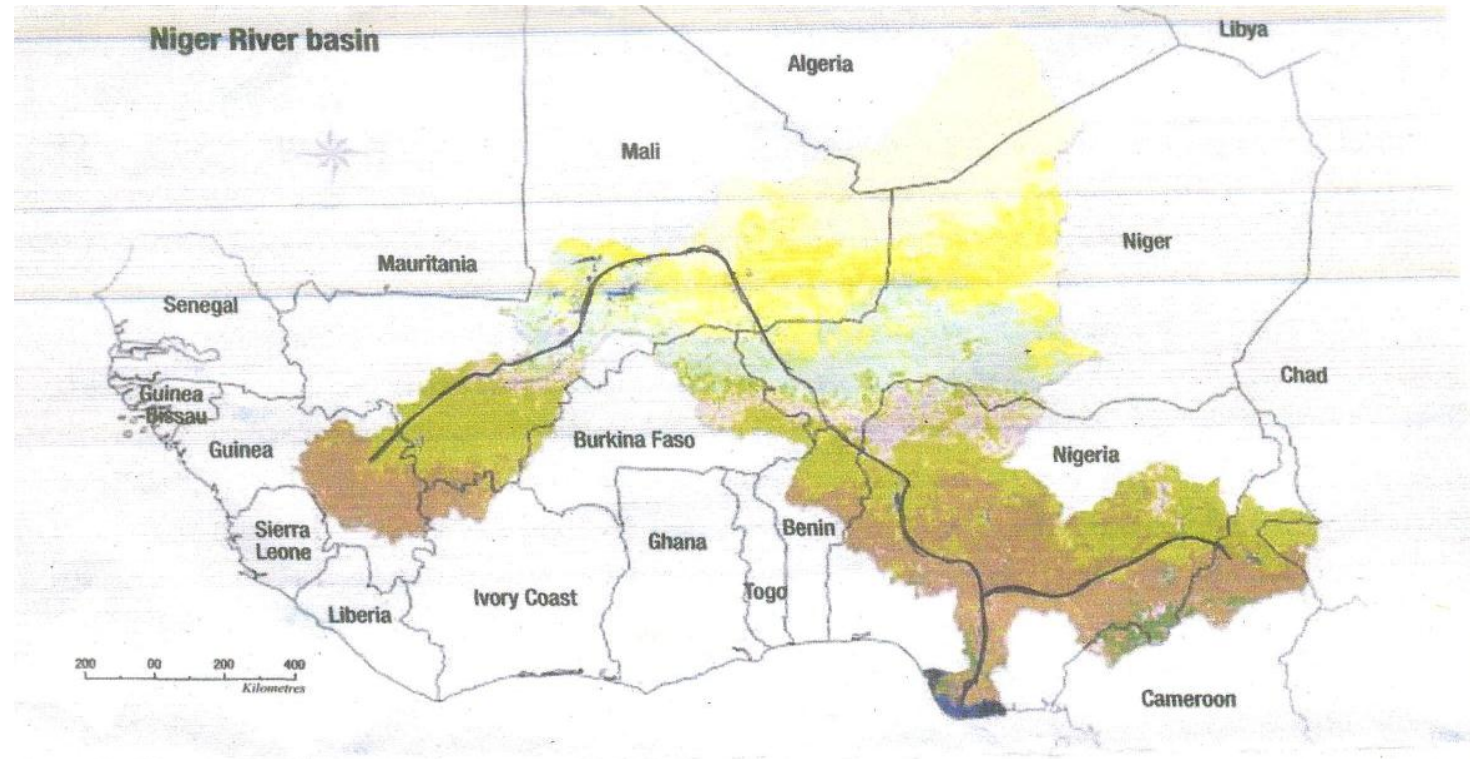

Figure1. Map of the Niger River Basin, showing countries that shared it (World Bank, 1995) 


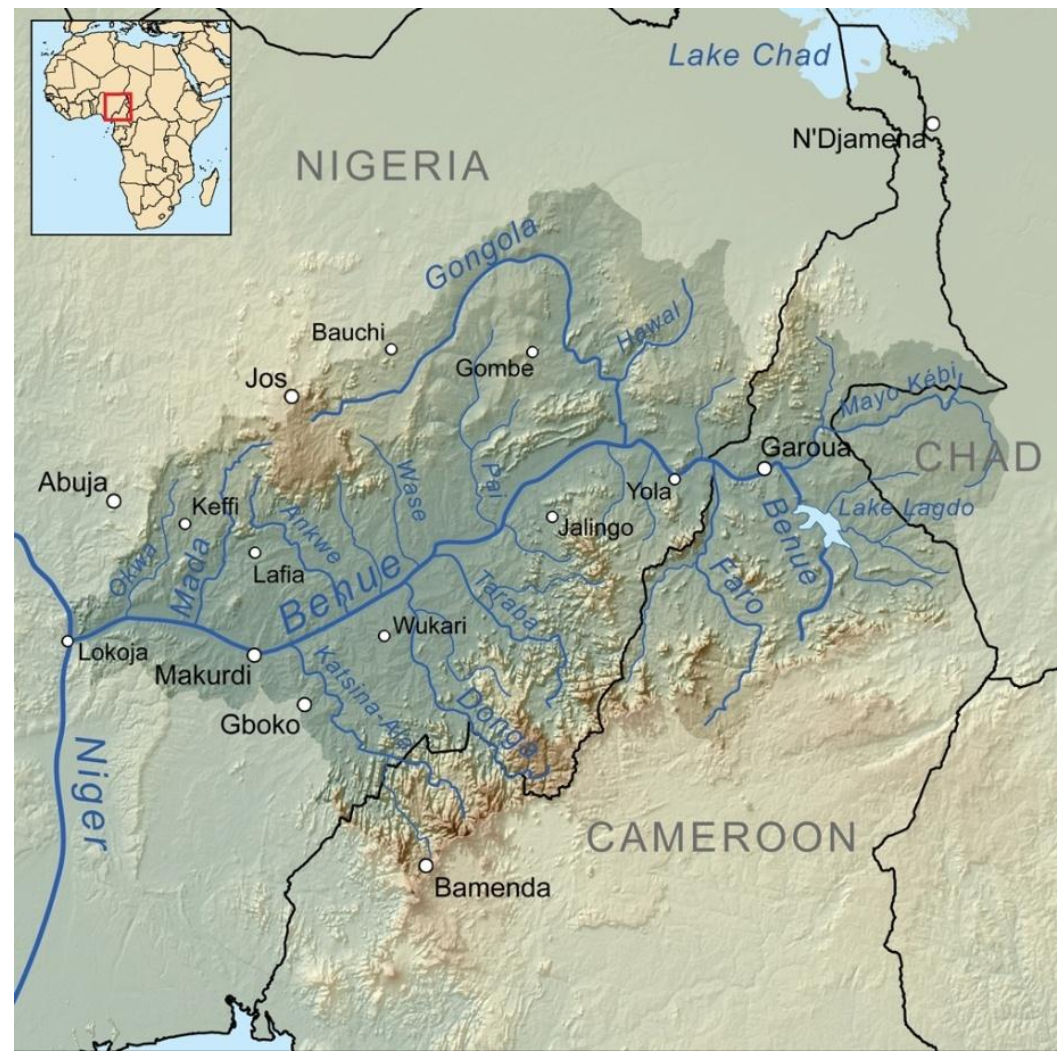

Figure 2: Map showing the Benue River drainage basin (www.en.wikipedia.org/Benue_River)

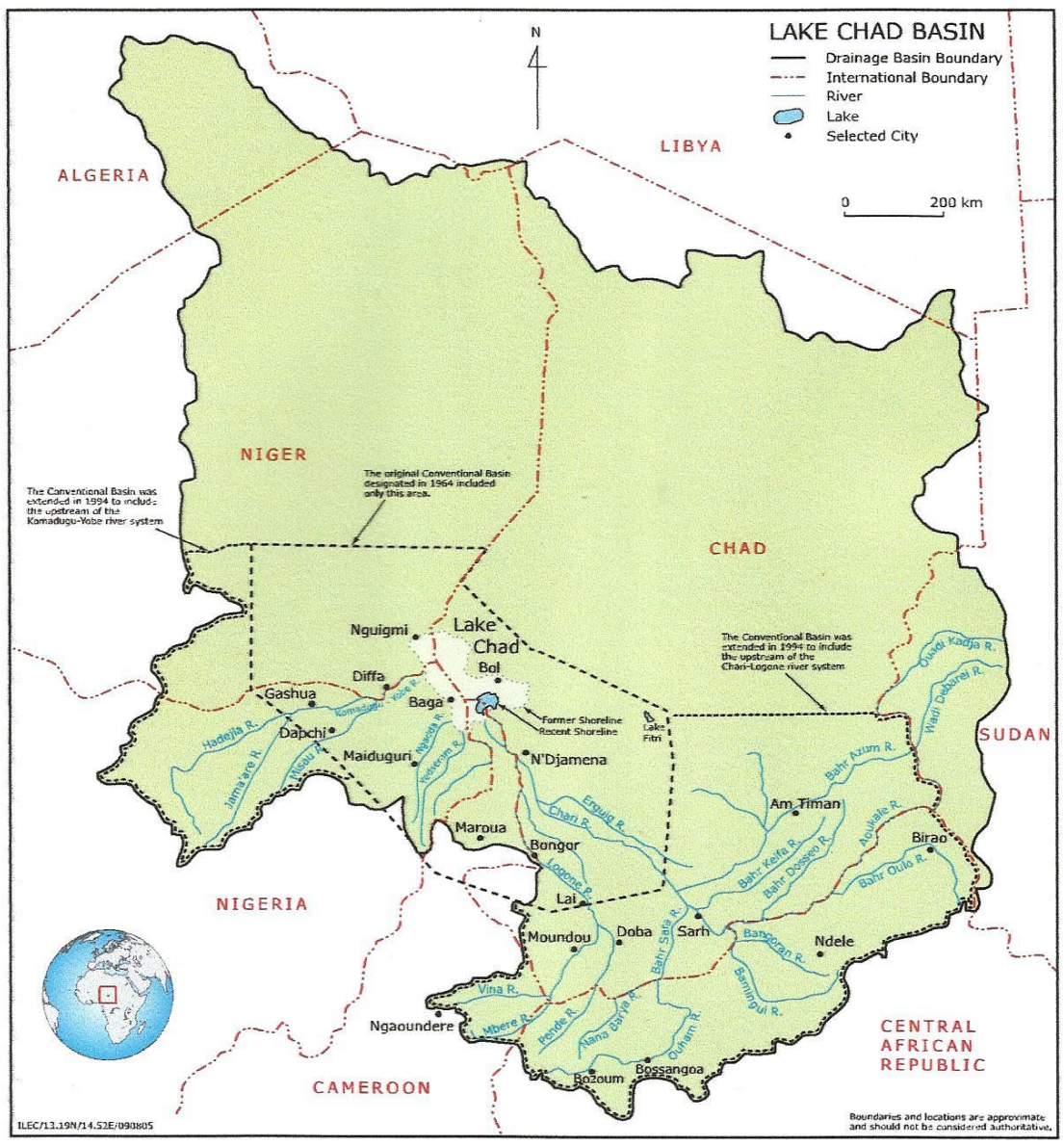

Figure 3: The Lake Chad Drainage and Conventional Basins (Eric and Johnson, 2006). 


\section{Addressing the Problems of Water Scarcity and water-related conflicts in Nigeria.}

With water scarcity in Nigeria, water-related conflicts between Nigeria and other countries sharing rivers together are inevitable. The following measures have to be employed to reduce water scarcity in Nigeria and avoid water-related conflicts among countries sharing rivers together.

\section{VI.1. Dam Construction}

It is necessary to consider seriously the riparian rights of the riverine dwellers in the proposal, design and construction of dams, particularly large dams. The rivers of the Sahel region of Nigeria, viz river SokotoRima, Yobe and Gongola, have been subjected to large-scale irrigation scheme, for example, Kano River project, Hadejia valley projects, south Chad projects, covering hundreds of thousands of hectares and requiring large quantities of water. The effect of such projects on the downstream users appears capable of generating inter communal feuds both within and outside the country. As much as possible, big dam construction should be discouraged particularly in the Sahel region of the country, to minimize large-scale evapotranspiration and unnecessary water loss through that process, except, probably for artificial recharge of the groundwater aquifers. Where this is absolutely necessary, after the Cost Benefits analyses has been found to be favorable, adequate steps should be taken to put in place relevant water and environmental management program to ameliorate the effect on the ecosystem.

\section{VI.2 Rainwater Harvesting}

This is a technology used for collecting and storing rainwater from rooftops, the land surface or rock catchments using simple techniques such as jars and pots as well as more complex techniques such as underground check dams. The techniques usually found in Asia and Africa arise from practices employed by ancient civilizations within these regions and still serve as a major source of drinking water supply in rural areas. Commonly use systems are constructed of three principal components; namely, the catchment's area, the collection device, and the conveyance system.

\section{VI.3 Channelization of River Niger}

The River Niger south confluence with the River Benue collects a lot of the runoff water from the inland basins. With proper channelization, all the floodwaters will be conveyed into the sea with minimal over flow into bordering villages. Apart from preventing the damages caused by flooding, the direct discharge into the sea will help to maintain the sea water/fresh water equilibrium and minimize inland intrusion of the sea.

\section{VI.4 Water Resources Management}

It has been stated interlaid, that the management of the water resources implies the management of the hydrologic cycle, within the catchments area. The problem of water resources management in Nigeria has been subject of discussion for sometimes now. For proper management practice, it is necessary to highlight the need, to quantify the available water resources, both surface and groundwater, in any situation, through a well coordinated water resources study. Water should be shared to the different sectors to minimize over exploitation of water resources in Nigeria.

\section{VI.5 Artificial Water Recharge}

Artificial recharge may be defined as augmenting the natural movement of surface water into underground formation by methods of construction, by spreading of water, or by artificially changing natural condition. A variety of methods have been developed including water spreading, recharging through pits and wells and pumping to induce recharge from surface water bodies. The choice of a particular method is governed by mark topographic, geologic and soil conditions, the quality of water to be recharged and the ultimate use. In Nigeria, Lake Chad is a good example where artificial recharging of groundwater can be applied. Artificial recharging began in Europe early in the nineteen century, since then recharge installations have steadily increased throughout the world. Today in California alone 276 artificial recharge projects operate in areas where groundwater has been extensively exploited.

\section{VI.6 Inter-Regional Water Transfer}

In order to enhance and sustain the flow of the rivers and maintain the wetland resources and the ecological balance in the Sahel region of the country, a serious consideration must be given to ensuring that the major rivers via: Rivers Lagone, and Chari, supplying water to the Lake Chad, and not capturing by either the River Benue or any of the tributaries of the River Congo. Efforts should also be made to arrest the dwindling water resources of the Lake area through inter-catchments transfer of water from the two rivers. The water transfer from the Congo basin into Chad was proposed by Umolu et al, (1986) may be seriously considered. Also, sufficient water should be released intermittently from the big dams on the River Niger and River 
Chalawa, to sustain the wetland resources and the river alluvium aquifers, down stream of that part of the country.

\section{VI.7 Management Plans for the River Basins}

At the international scale of a water-based conflict or dispute between two or more countries, some principles of the international law provide a solid foundation for negotiation and arbitration. However, it is clearly in the interest of individuals and societies that appropriate national and international institutions should jointly develop management plans to shared river basins and also derived workable protocols that can be used to prevent water-based conflict in the regions.

\section{VI.8 Water Treaties}

These are water rights that provide safe, clean water for millions of people around the world. "Lack of safe water contributes to an estimated $80 \%$ of diseases and death in the developing world" said Human Development Report (2006). They added that in 20 years, 2 out of 3 people in the world will suffer from shortages if no action is taken now decisively.

\section{Conclusion}

Today, people and Government of Nigeria are looking at water as an infinite resource thereby, ignoring its real value. Rather, more attention is given to the oil and mineral sectors. There is water scarcity in Nigeria as a result of increase in population growth, pollution, climate change, and shrinking of lakes, rivers, and disappearing of certain living organisms. Presently, without River Niger and River Benue, Nigeria is an absolute water scarce country. The water related conflicts likely to be faced by Nigerian, at present and time to come, are food scarcity and regional instability. Nigeria which is at the receiving end should take the "bull by the horn" by calling for a common ground that will avail countries sharing rivers with it to derive a workable agreement that will avoid regional conflicts in the future.

\section{References}

[1]. Christopher, O.O., (2006). Water Resources, Environment and Sustainable Development in Nigeria: Jour. Hum. Ecol, 19(3), pp 169-181.

[2]. Eric, O.O., Lekan, O., and Jonhson, A.O., (2006). Lake Chad, Experience and Lessons Learned Brief.

[3]. Falkemark, M., (1989a). "The Massive Water Scarcity Now Threatening Africa-why isn't being addressed?:Ambio 18(2), pp112118.

[4]. Falkemark, M., (1989b). "Vulnerability Generated by Water Scarcity Synopsis": Ambio 18(6), pp 352-353.

[5]. Federal Republic of Nigeria Official Gazette, (2007). National Population: Vol. 94: Printed and Published by Federal Government of Nigeria.

[6]. Gusikit, R.B., (2008). Water Scarcity and Water Related Conflicts in Nigeria: M.Sc. Thesis (Unpublished), pp 1-35.

[7]. Human Development Report, (2006). Beyond Scarcity: Power, poverty, and the global water crises, published for United Nations Development Programme, pp 133-170.

[8]. Imo, J.E., andEkpenyong, N., (2011). Extreme Climatic Variability in North-western, Nigeria: An analysis of Rainfall Trends and Patterns, Journal of Geography and Geology, pp 51-54.

[9]. Lar, U.A.,Daspan,R.I., Dibal, H., Agati, J., and Lekmang, I., (2007). Geology and Mineral Resources of Plateau State: Jos University Press, Ltd Jos, pp 1-11

[10]. Offodile, M.E., (2002). Groundwater Study and Development in Nigeria: Mecon Geology and Engineering Service LTD., Nigeria, pp 48-52.

[11]. Oluwayinka, D., (2013). Expert predicts food scarcity in Nigeria: how prepared are we?Nigeria Tribune, Wednesday, 10 April, 2013.

[12]. Umolu, J.C., and Oke, V.O., (1986). Zaire-Chad-Niger Interbasin: Records of the Geol., Survey, pp 46-56.

[13]. United Nations, (1991). Population, Resources and the Environment: United Nation Population Fund, New York.

[14]. World Bank, (1995). Defining an Environmental Development Strategy for the Niger Delta, Vol.2, Industry and Energy Operations Division, Washington, D.C.

[15]. World Bank, (2002). GEF Project on the Reversal of Land and Water Degradation Trends in the Lake Chad Basin: World Bank,Washington, D.Cwww.en.wikipedia.org/Benue River 